\title{
Characterization of a birnavirus isolated from diseased turbot cultured in Spain
}

\author{
B. Novoa ${ }^{1}$, A. Figueras ${ }^{1}$, C. F. Puentes ${ }^{1}$, A. Ledo $^{2}$, A. E. Toranzo ${ }^{2}$ \\ ${ }^{1}$ Instituto de Investigaciones Marinas, CSIC, Eduardo Cabello 6, E-36208 Vigo, Spain \\ ${ }^{2}$ Departamento Microbiología y Parasitología, Facultad de Biología, Universidad de Santiago, E-19706 Santiago de Compostela, Spain
}

\begin{abstract}
During 1989, light but persistent mortalities were detected in a turbot Scophthalmus maximus L. farm in Galicia (northwestern Spain) and a virus with the characteristics of a birnavirus was isolated. The purpose of this study was to characterize the viral agent and determine the susceptibility of turbot to this virus. Electron microscopic examination revealed that the particles were isometric, hexagonal and unenveloped with an average diameter of 58 to $60 \mathrm{~nm}$. The molecular weights of the RNA segments were 1.9 and $2.0 \times 10^{6}$ daltons. The cells most susceptible to the turbot isolate were the CHSE-214, FHM and RTG-2 lines and the optimal temperature range for its replication was 15 to $20^{\circ} \mathrm{C}$. The RNA and polypeptide electropherotypes show that this virus resembles the Ab serotype of infectious pancreatic necrosis virus (IPNV); however, it differs in that it replicates in the FHM cell line and is not neutralized by antisera to the classical serotypes of IPNV. Infectivity trials conducted in turbot of different sizes indicated that the virus produced mortality only in small fish $(2 \mathrm{~g})$, although the la:ger fish ( $30 \mathrm{~g})$ harbored the virus for at least $35 \mathrm{~d}$. Fish inoculated with this isolate showed no pancreatic necrosis although necrosis of the hematopoietic elements of the kidney and spleen was detected.
\end{abstract}

\section{INTRODUCTION}

Over the past 5 yr there has been a considerable increase of turbot Scophthalmus maximus L. farming in Galicia (northwestern Spain) with a production of about $900 \mathrm{t}$ in 1991. This increased development of turbot culture has been accompanied by an increase in disease problems involving bacterial, viral and parasitic infections (Toranzo et al. 1990, Fernández-Puentes et al. 1991).

There were few reports of viral agents being detected in farmed turbot prior to 1987. A herpesvirus was seen by electron microscopy in turbot suffering mortalities following their movement from a hatchery in Scotland to a warm-water growing site; however, no virus was isolated (Buchanan et al. 1978). Hill (1982) isolated infectious pancreatic necrosis virus (IPNV) from abnormal eggs of turbot. However, during the past 5 yr, there have been a number of isolations made from turbot. An IPN virus of the Ab serotype was found in 7 mo old turbot during an epizootic that occurred when asymptomatic carriers were transferred from the farm where they were kept at $14^{\circ} \mathrm{C}$ to experimental facilities supplied with sea water at $18^{\circ} \mathrm{C}$ (Castric et al. 1987). Significant mortalities have been detected in marine species (turbot and Atlantic salmon Salmo salar) in Norway and they were attributed to a new serotype of IPNV named N1 (Christie et al. 1988, Mortensen et al. 1990). Lupiani et al. (1989) reported the isolation in Spain of a member of the aquareovirus group, the TRV (turbot rotavirus), which possesses distinctive antigenic and molecular properties from other rotaviruses (Dopazo et al. 1992, Samal et al. 1991). A recent study described a natural outbreak of encephalomyelitis among larval turbot causing high levels of mortalities. The neurotropic character of the disease suggests that the virus might be a member of the family Picornaviridae (Bloch et al. 1991). The latest virus from turbot was isolated in a natural outbreak of viral hemorrhagic septicaemia (VHS) in Germany (Schlotfeldt et al. 1991).

Since 1989 several birnavirus-like viruses have been isolated from salmon and turbot in Galicia (Ledo et al. 1990. Novoa et al. 1991). Interestingly, the majority of these viruses were detected during routine microbiological surveys from fish without clinical signs of 
disease. The purpose of this study was to characterize virus strain TB-306 isolated from cultured turbot. In addition, pathogenicity tests were conducted in order to study the susceptibility of different size turbot to this particular isolate

\section{MATERIAIS AND METHODS}

Virus isolation. In 1989, light but persistent mortalities occurred in a turbot farm in Galicia. No characteristic symptoms were seen in the affected fish. The fish, weighing $30 \mathrm{~g}$ each, were reared in $4 \mathrm{~m}^{3}$ concrete tanks, with a continuous water flow of $2000 \mathrm{l} \mathrm{h}^{-1}$ and at a density of $5 \mathrm{~kg} \mathrm{~m}^{-3}$. As no parasites or bacteria could be detected in moribund or dead fish, virologicai analyses were conducted. Spleen and kidney tissues were removed, pooled and processed using standard virological procedures (Amos 1985).

Cell culture and media. The chinook salmon embryo (CHSE-214) and rainbow trout gonad (RTG-2) cell lines were used for primary isolation and for virus assays. Other fish cell lines used were derived from bluegill (BF-2), brown bullhead (BB), fathead minnow (FHM), Atlantic salmon (AS) and common carp (EPC).

Cells were cultivated in Eagle's minimal essential medium (MEM) supplemented with 10\% fetal bovine serum and containing $100 \mathrm{IU}$ penicillin and $100 \mu \mathrm{g}$ streptomycin $\mathrm{ml}^{-1}$. The CHSE-214, RTG-2 and AS lines were grown at $18^{\circ} \mathrm{C}$ and the BF-2, FHM, EPC, and $\mathrm{BB}$ lines at $25^{\circ} \mathrm{C}$. All fish cell lines were maintained at $15^{\circ} \mathrm{C}$ when monolayers were confluent.

Cell line specificity and optimal temperature of replication. Monolayer cultures of the above 7 fish cell lines grown in 24 well plates were inoculated with the turbot isolate at a multiplicity of infection (MOI) of 0.01 virus cell $^{-1}$ After a $30 \mathrm{~min}$ adsorption, $2 \mathrm{ml}$ of MEM with $2 \%$ fetal bovine serum were added to each well. Replicated plates were incubated at temperatures of $10,15,20$ and $25^{\circ} \mathrm{C}$. The cells were examined for $35 \mathrm{~d}$ for the appearance of cytopathic effects (CPE). When CPE were extensive, virus levels in the culture fluids were assayed in microtiter plates (COSTAR) and the tissue culture infective dose $\left(\mathrm{TCID}_{50}\right)$ determined according to Reed \& Müench (1938). Uninoculated wells of each cell line were used as controls.

Electron microscopy. For negatively stained preparations, RTG-2 cells infected at an MOI of $0.1 \mathrm{TCID}_{50}$ cell $^{-1}$ were incubated until CPE were evident. The culture medium was decanted and centrifuged at $2000 \times g$ for 15 min to pellet cell debris, and the supernatant centrifuged for $1 \mathrm{~h}$ at $100000 \times \mathrm{g}$. The pellet was resuspended in the smallest possible quantity of phosphate buffered saline (PBS). A drop of the virus concentrate was placed onto a Formvar coated grid and after 3 to $5 \mathrm{~min}$, the excess was rinsed off and the grid was covered with $2 \%$ phosphotungstic acid for $40 \mathrm{~s}$. Negatively stained virions were examined with a transmission electron microscope (Phillips $120 \mathrm{kV}$ )

Chloroform resistance and acridine orange staining. Chloroform resistance was assayed as described by Vestergård-Jørgensen (1972). A loss of virus infectivity greater than $90 \%$ (one log) indicated sensitivity of the virus to the treatment. Two control viruses, IPNV (Sp serotype) and infectious hematopoietic necrosis virus (IHNV), were included as resistant and sensitive viruses respectively. The acridine orange staining method was performed according to Kuchler (1977).

Viral RNA electrophoresis. Concentrated virus (pelleted at $100000 \times g$ for $1 \mathrm{~h}$ ) was treated with proteindse $\mathrm{K}\left(200 \mu \mathrm{g} \mathrm{mil} \mathrm{i}^{-1}\right)$ at $37^{\circ} \mathrm{C}$ for 30 to $60 \mathrm{~min}$. The solution was extracted with phenol and chloroform $(1: 1)$ and the RNA in the aqueous phase recovered by precipitation with ethanol. The nucleic acid precipitate was resuspended in $50 \mu \mathrm{l}$ of SSC $(0.15 \mathrm{M} \mathrm{NaCl}$ plus $0.015 \mathrm{M}$ sodium citrate) and 2 aliquots were made. One of them was treated with $1 \mu \mathrm{l}$ of RNase (Ribonuclease A $0.05 \%$ in distilled water) and the other was treated with $1 \mu \mathrm{l}$ of DNase $\left(1 \mathrm{mg} \mathrm{ml}^{-1}\right.$ in $0.15 \mathrm{M} \mathrm{NaCl}, 50 \%$ glycerol). Both aliquots were incubated at $37^{\circ} \mathrm{C}$ for $30 \mathrm{~min}$. Samples were mixed with sample buffer boiled for $5 \mathrm{~min}$ and analyzed by SDS-PAGE (Laemmli 1970) using $7.5 \%$ polyacrylamide gels, which were run for $18 \mathrm{~h}$ at $150 \mathrm{~V}$. The RNA bands were visualized by staining with silver nitrate (Blum et al. 1987). The RNA segments of a turbot rotavirus were used as molecular weight markers (Samal et al. 1991).

SDS-PAGE analysis of virion polypeptides. RTG-2 cells grown on 24-well plates were infected at a multiplicity of infection of $1 \mathrm{TCID}_{50}$ cell $^{-1}$. After $1 \mathrm{~h}$ of adsorption, MEM with $2 \%$ FBS was added and the uncovered plates were irradiated with UV light (44 ergs $\mathrm{s}^{-1} \mathrm{~mm}^{-2}$ at $25 \mathrm{~cm}$ ) as described by Dobos \& Rowe (1977). This treatment greatly reduced cellular protein synthesis and allowed the detection of even minor virus-specific proteins. Five hours later, $10 \mu \mathrm{Ci}$ $\mathrm{ml}^{-1}$ of ${ }^{35}$ S) methionine (specific activity $1000 \mathrm{Cl}$ $\mathrm{mmol}^{-1}$ ) in methionine-free medium were added for $3 \mathrm{~h}$. The cells were washed 3 times with PBS and suspended in $200 \mu \mathrm{l}$ of $0.1 \mathrm{~N} \mathrm{NaOH}, 1 \%$ SDS and $200 \mu \mathrm{l}$ of sample buffer. The samples were boiled for 2 min and then subjected to SDS-PAGE on a $12 \%$ polyacrylamide gel. The gel was run for $5 \mathrm{~h}$ at $11 \mathrm{~mA}$. The polypeptide bands were stained with $1 \%$ Coomassie Brilliant Blue. The gel was treated twice with dimethylsulfoxide (DMSO) for 30 min, once with $20 \%$ of 2,5-diphenyloxazole (PPO) in DMSO for $3 \mathrm{~h}$ and then washed with water. After this treatment, the gel was dried and autoradiography was done on X-ray film (Kodak). 
Neutralization assays. The possible relationship of the turbot isolate to 3 serotypes of IPNV (Sp, Ab and Vr-299) was examined using specific rabbit antisera against these viruses. Virus stocks were diluted to contain $10^{2}$ to $10^{3}$ TCID $_{50} \mathrm{ml}^{-1}$ and were mixed with dilutions of the antisera ranging from $1 / 10$ to $1 / 200000$ (Dopazo 1991). The neutralization antibody titers were calculated according to the Reed \& Müench (1938) method and expressed as the reciprocal of the highest dilution of the antiserum protecting $50 \%$ of the inoculated wells.

Virulence assays in turbot. The turbot birnaviruslike agent (strain TB-306) was propagated in RTG-2 cells and the cell lysate was used as the inoculum. Turbot, previously testing negative for virus, were used.

Sixty large turbot (average weight $30 \mathrm{~g}$ ) and 60 small ones (average weight $2 \mathrm{~g}$ ) were inoculated intraperitoneally with $0.1 \mathrm{ml}$ of a virus suspension containing $10^{6}$ or $10^{5}$ TCID $_{50} \mathrm{ml}^{-1}$. Fish were maintained at $15^{\circ} \mathrm{C}$ in 251 tanks using recirculated sea water with aeration. In all the experiments the controls were treated as the infected fish and were inoculated with culture medium. Inoculated individuals were divided into 2 tanks. In one of them, dead fish were collected for virus assays. In the other tank, samples of 2 fish were taken weekly for histology and pools of brains, kidney, spleen and liver from 5 fish were collected for virus assays. At the same time, controls were collected for histology and virus assays.

Histopathology. Transverse sections, approximately $5 \mathrm{~mm}$ thick, of brain, kidney, spleen and liver were excised, fixed in $4 \%$ buffered formalin, embedded in paraffin, sectioned at $5 \mu \mathrm{m}$ and stained with hematoxylin and eosin.

\section{RESULTS}

Virus isolation

A cytophatic effect, characteristic of IPNV, was observed $10 \mathrm{~d}$ after inoculation of tissue homogenates onto RTG-2 and CHSE-214 cells (Fig. 1). The shape and size of the turbot isolate (TB-306) were indistin-
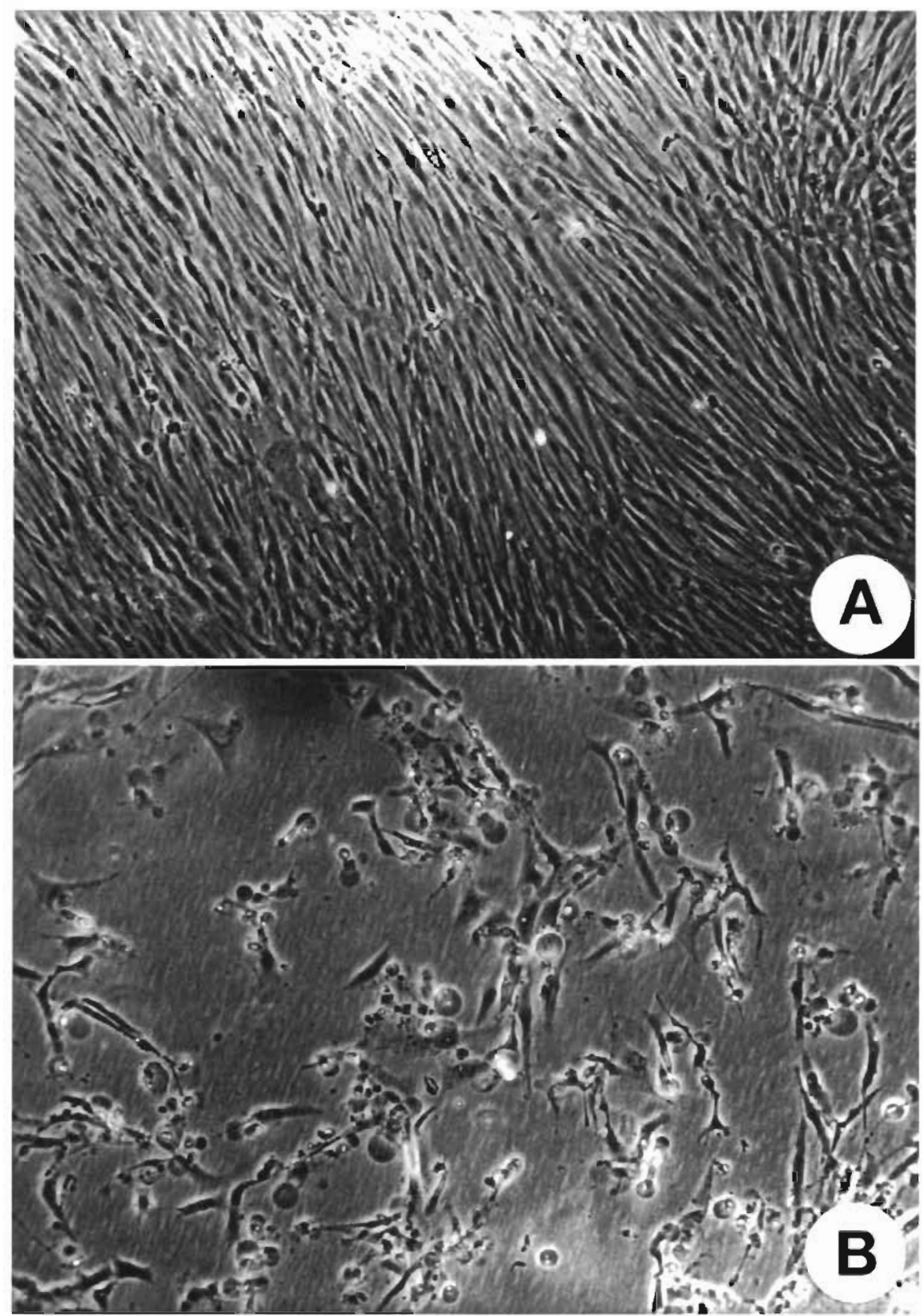

Fig. 1. (A) Normal RTG-2 cells and (B) RTG-2 cells showing cytopathic effects characteristic of IPNV observed $10 \mathrm{~d}$ after inoculation of tissue homogenates with turbot isolate TB-306. $\times 200$ 
guishable from the other serotypes of IPNV. The particles were isometric, hexagonal and unenveloped with an average diameter of 58 to $60 \mathrm{~nm}$. The distinctive morphology of the virions and the characteristic CPE suggested that this isolate was a birnavirus

\section{Biochemical properties and serological assays}

The infectivity of the virus TB-306 was not affected by chloroform treatment, which suggests that it is a non-enveloped virus. The IPNV and IHNV control viruses employed were resistant $(<1.0 \log$ drop in infectivity titer) and sensitive ( $>5 \log$ drop) to chloroform treatment respectively. Acridine orange staining of intected RTG-2 cultures showed a yeilowish green cytoplasm, which is indicative of the formation of a double-stranded nucleic acid. In uninfected cells, the cytoplasm had a dull red color (single-stranded RNA).

The RNA of the turbot isolate consisted of 2 segments when analyzed by gel electrophoresis. These 2 segments appeared even after RNase and DNase treatment, which shows that the virus is double-stranded RNA. The sizes of both segments were similar to those of the serotype $\mathrm{Ab}$ but differed from the other reference serotypes (Fig. 2). The molecular weights of the RNA segments of the isolate were 1.9 and $2.0 \times 10^{6}$ daltons, respectively.

The pattern of the virion protein bands of the turbot isolate in SDS-PAGE was similar to those obtained with the reference Ab strain of IPNV (Fig. 3). However, none of the antisera against the reference IPNV strains $A b, S p$ and VR-299 totally neutralized the turbot isolate (Table 1).

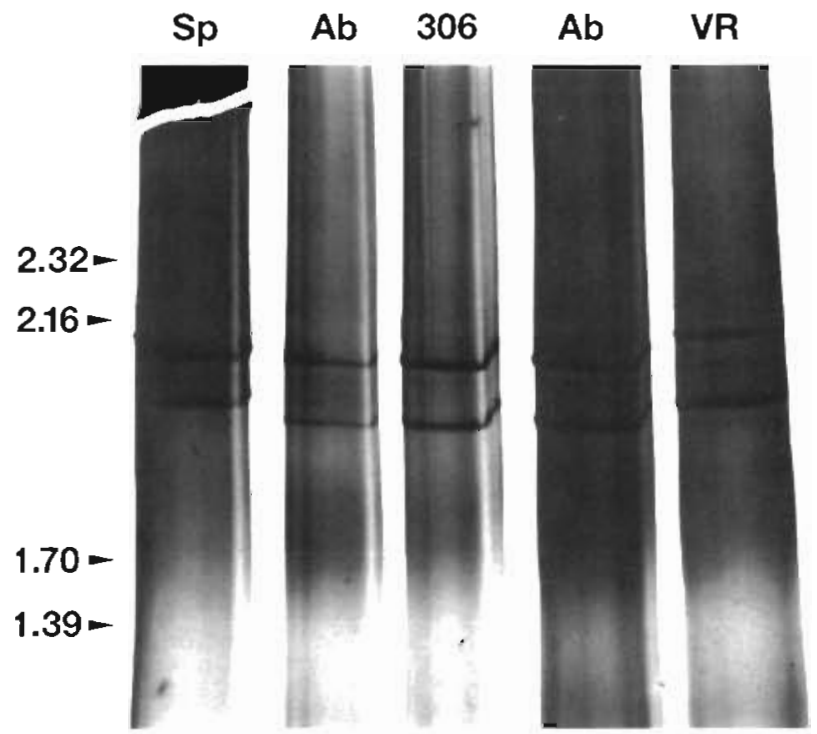

Fig. 2. Comparison of the RNA of the reference strains of IPNV with turbot 1solate TB-306 by gel electrophoresis. The position of known RNA molecular weight markers $\left(\times 10^{6}\right)$ in the same gel are shown in the left margin

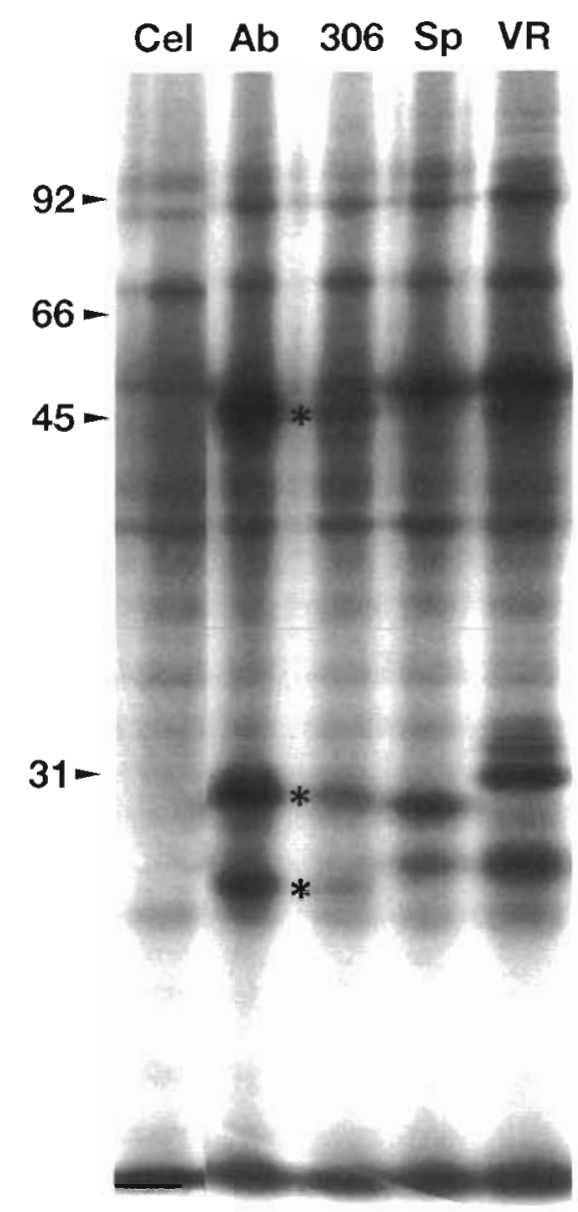

Fig. 3. Gel electrophoresis showing the pattern of protein bands of turbot isolate TB-306, the IPNV controls and uninfected cells. Numbers: positions of the molecular weight markers in kilodaltons; *: similarity between TB-306 and the $A B$ strain

\section{Cell specificity and incubation temperature}

The cell lines most susceptible to the turbot isolate were CHSE-214, FHM and RTG-2. The BF-2, EPC and $\mathrm{BB}$ lines were less susceptible to this particular IPN isolate and the AS cell line was refractory. The optimal

Table 1. Antigenic relationship of the turbot isolate (TB-306) with reference birnavirus strains

\begin{tabular}{|lccr|}
\hline $\begin{array}{l}\text { Virus } \\
\text { strain }\end{array}$ & Sp & $\begin{array}{c}\text { Antisera } \\
\text { Ab }\end{array}$ & VR-299 \\
\hline $\mathrm{Sp}$ & $7079^{\circ}$ & 316 & 2985 \\
$\mathrm{Ab}$ & 1258 & 14125 & 5956 \\
$\mathrm{VR}-299$ & 3458 & 4216 & 44668 \\
$\mathrm{~TB}-306$ & 1258 & 1995 & 2985 \\
${ }^{\mathrm{a}}$ Reciprocal of the antiserum dilution protecting $50 \%$ of \\
the test cultures against 100 to 1000 TCID
\end{tabular}


Table 2. Cell culture spectrum and optimal temperature for replication of turbot isolate

\begin{tabular}{|c|c|c|c|c|c|c|c|}
\hline $\begin{array}{l}\text { Temperature } \\
\left({ }^{\circ} \mathrm{C}\right)\end{array}$ & CHSE & EPC & AS & $\begin{array}{l}\text { Cell lines } \\
\text { FHM }\end{array}$ & RTG-2 & $\mathrm{BB}$ & $B F-2$ \\
\hline 10 & $\begin{array}{c}2 / 10^{a} \\
\left(1.0 \times 10^{7}\right)^{b}\end{array}$ & $4 /-$ & - & $\begin{array}{c}5 / 25 \\
\left(1.9 \times 10^{5}\right)\end{array}$ & $\begin{array}{c}5 / 30 \\
\left(5.6 \times 10^{5}\right)\end{array}$ & - & - \\
\hline 15 & $\begin{array}{c}2 / 5 \\
\left(1.8 \times 10^{7}\right)\end{array}$ & $2 /-$ & - & $\begin{array}{c}2 / 11 \\
\left(5.0 \times 10^{6}\right)\end{array}$ & $\begin{array}{c}3 / 19 \\
\left(1.0 \times 10^{7}\right)\end{array}$ & $23 /-$ & - \\
\hline 20 & $\begin{array}{c}6 / 8 \\
\left(1.2 \times 10^{7}\right)\end{array}$ & $2 /-$ & - & $\begin{array}{c}3 / 31 \\
\left(1.9 \times 10^{6}\right)\end{array}$ & $\begin{array}{c}3 / 21 \\
\left(3.2 \times 10^{6}\right)\end{array}$ & $\begin{array}{c}14 / 30 \\
\left(1.1 \times 10^{5}\right)\end{array}$ & $30 /-$ \\
\hline 25 & NT & $\begin{array}{c}6 / 25 \\
\left(1.9 \times 10^{5}\right)\end{array}$ & NT & $\begin{array}{c}2 / 9 \\
\left(1.0 \times 10^{6}\right)\end{array}$ & $N T$ & $\begin{array}{c}14 / 21 \\
\left(3.2 \times 10^{5}\right)\end{array}$ & $19 /-$ \\
\hline \multicolumn{8}{|c|}{$\begin{array}{l}\text { (Days to appearance of CPE)/(Days to total destruction of mo } \\
\text { "Virus titer when destruction of the monolayer was complete } \\
\text { - No CPE or total destruction detected after } 30 \mathrm{~d} \\
\text { NT. Not tested because the cells cannot be maintained in }\end{array}$} \\
\hline
\end{tabular}

temperature range for the replication of TB-306 isolate was 15 to $20^{\circ} \mathrm{C}$. At $25^{\circ} \mathrm{C}$ there were CPE and cell destruction of EPC, FHM and BB cells (Table 2). The titer of the lysate from FHM at $15^{\circ} \mathrm{C}$ was $5 \times 10^{6}$, a value almost as high as is obtained in CHSE-214 $\left(1.8 \times 10^{7}\right)$ and RTG-2 $\left(1.0 \times 10^{7}\right)$ cells; however, the time required to obtain monolayer destruction was longer than in CHSE-214 or RTG-2.

\section{Pathogenicity tests}

In order to assess the possible significance of the virus for turbot culture, infectivity trials were conducted in juvenile fish of different sizes $(30 \mathrm{~g}$ and $2 \mathrm{~g}$ ). After 2 mo, no mortalities were recorded in $30 \mathrm{~g}$ fish, but the virus was recovered from liver, kidney and spleen tissues (Fig. 4). The highest titer was found in

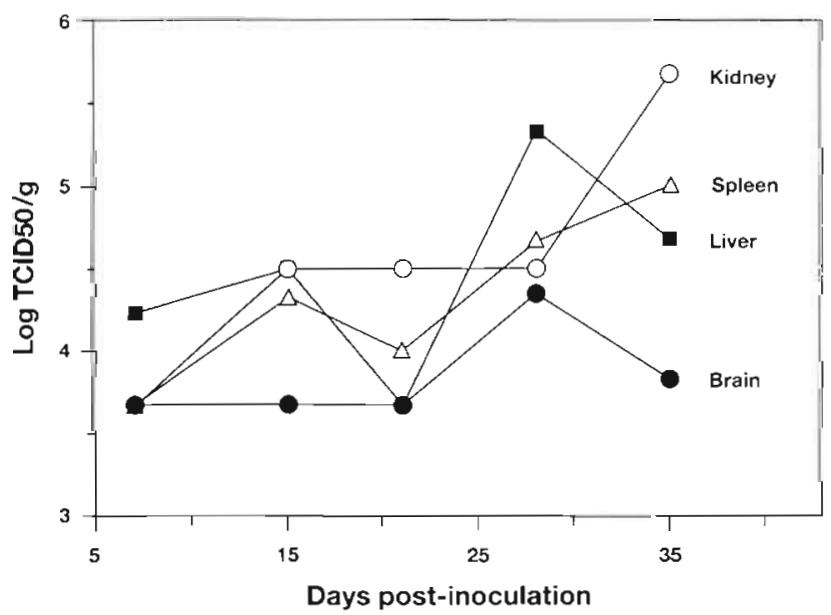

Fig. 4. Virus titers in the different organs of experimentally infected $30 \mathrm{~g}$ turbot Scophthalmus maximus at various postinoculation intervals the kidney, whereas the brain displayed the lowest virus recovery, ranging from $5 \times 10^{3}$ to $3 \times 10^{4} \mathrm{TCID}_{50}$ $\mathrm{g}^{-1}$. An increase in viral titer with time was observed in the kidney and spleen. In fish weighing $2 \mathrm{~g}$, all the individuals were dead after $13 \mathrm{~d}$, and virus was recovered from all fish at titers greater than $3.2 \times$ $10^{6} \mathrm{TCID}_{50} \mathrm{~g}^{-1}$.

Externally the fish inoculated with this isolate appeared normal. No pancreatic necrosis or sloughing of the mucosa was found, although a necrosis of the hematopoietic elements was detected in the kidneys and spleens of $30 \mathrm{~g}$ fish (Fig. 5).

\section{DISCUSSION}

At present the number of birnaviruses associated with mortalities in marine fish is low (Dorson 1983, McAllister et al. 1984). In an epidemiological study conducted over a $2 \mathrm{yr}$ period in turbot and salmon in our area, most IPN-like viruses were isolated from apparently healthy fish. Only on a few occasions were they associated with diseased fish (Ledo et al. 1990, Novoa et al. 1991). In this study, the isolate TB-306, presumptively associated with turbot mortalities, was demonstrated to be a member of the Birnaviridae with RNA and polypeptide patterns similar to the Ab serotype. However, in contrast to the Ab strain described by Castric et al. (1987), our strain is not neutralized to the same extent by $\mathrm{Ab}$ antiserum, and it can replicate in the FHM cell line, thus differing from the reference $A b$ serotype, which does not replicate in the FHM cell line (Dorson 1983, MacDonald \& Gower 1981). This isolate appears to be a member of the aquatic birnavirus serogroup $A$ but is not one of any of the 3 serotypes tested. 


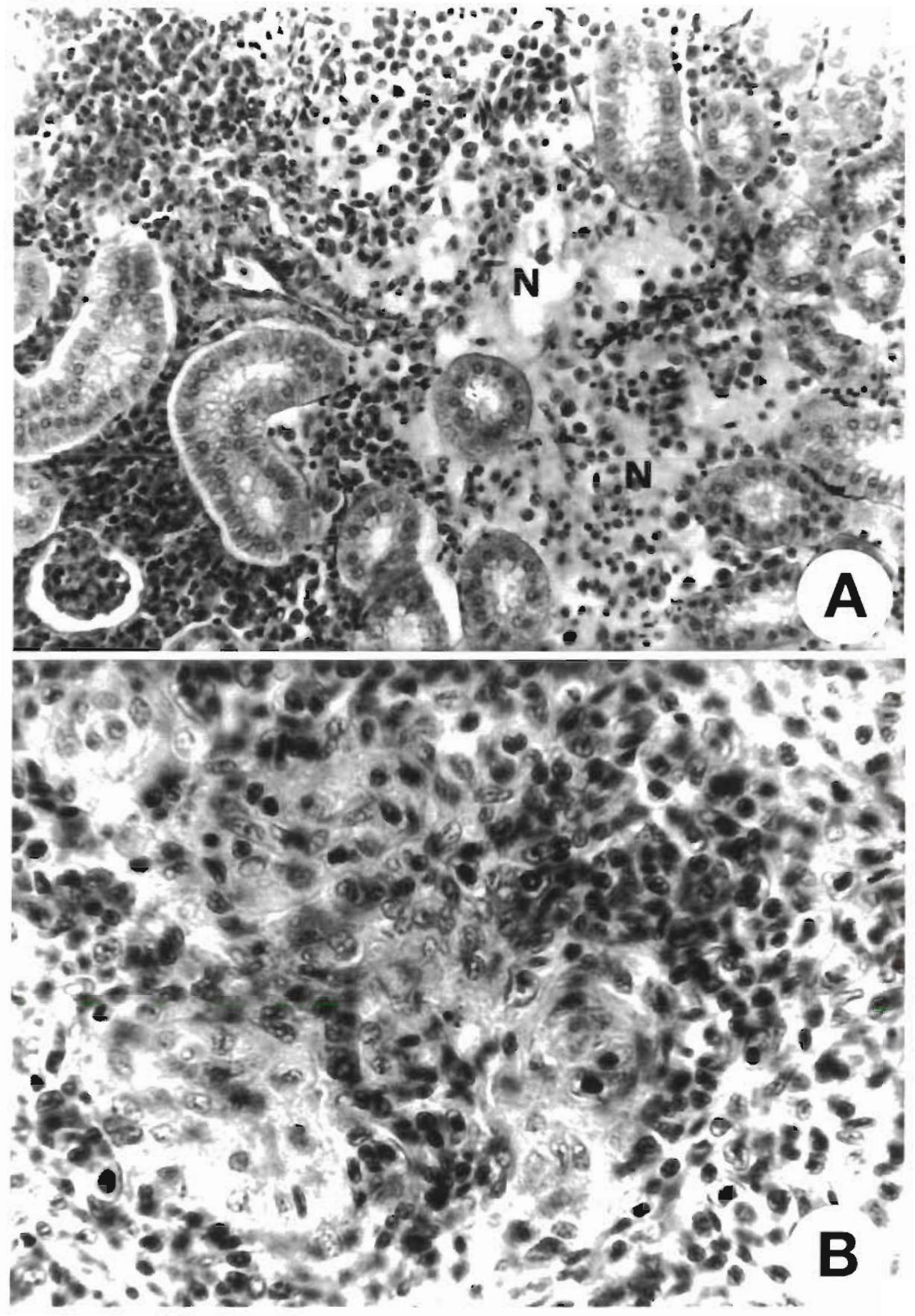

Fig 5. Hematopoietic necrosis (N) detected in (A) the kidney and (B) the spleen of turbot Scophthalmus maximus experimentally infected with birnavirus strain TB-306 (A) $\times 400 ;(B) \times 1000$

McAllister et al. (1984) reported isolation of an IPN virus from southern flounder Paralichthys lethostigma that shared characteristics of the Ab and Sp serotypes, but was assumed to belong to the Ab serotype because of its cell culture specificity and relative avirulence for salmonids. They postulated that this agent might represent an antigenic intermediate with bivalent reaction sites or multiple discrete antigens. On the other hand, Hedrick et al. (1986) found that comparisons of the virion polypeptides and RNA segments of new isolates are helpful in determining the identity of individual virus strains. In addition, MacDonald \& Gower (1981) reported that the study of the patterns of RNA might show more diversity than serological methods. Our results, together with all the findings reported above, indicate that a standardization in identification assays between different laboratories is urgently needed.

It is interesting to note that in experimental infections in turbot, mortalities appeared only in the younger individuals (1 mo old), which is similar to the pathogenicity of IPNV for salmonids (Dorson \& Torchy 1981, McAllister \& Owens 1986). Although no mortalities occurred in the older fish, the virus was recovered from all individuals, which indicates that virus can persist in asymptomatically infected turbot. Although the kidney proved to be the best organ for isolation of the virus in surviving turbot, similar to what has been reported in salmonids, the virus was also isolated from the brain.

The birnavirus isolated from turbot did not produce necrosis of the pancreatic tissue; however, it does produce necrosis of the hematopoietic tissue in the kidney and spleen, which is in agreement with the results of Castric et al. (1987). Both isolates seem to be pathogenic for this species but to a different degree, our isolate being less virulent than the French isolate. Another virus similar to IPNV Ab serotype is the EVE virus isolated from Anguilla japonica (Sano et al. 1981), which is pathogenic for eel 
but not for rainbow trout. Experimental inoculation of trout with the turbot isolate is being conducted in order to determine if it produces pancreatic necrosis and mortality.

Further studies are required to elucidate the differences between this virus and other Ab strains of IPNV.

Acknowledgements. We thank R. P. Hedrick and J. Castric for providing the antisera and the reference viral strains used in this study. We also thank 'Piscicola del Morrazo S. A.' for providing the fish used in the experimental infections. This work was supported by Grants MAR 89-0270 from the Comision Interministerial de Ciencia y Tecnología (CICYT), and by XUGA 70708888 from Xunta de Galicia, Spain. Beatriz Novoa acknowledges the Ministerio de Educación y Ciencia (Spain) for a research fellowship.

\section{LITERATURE CITED}

Amos, A. H. (1985). Procedures for the detection and identification of certain fish pathogens, 3rd edn. Fish Health Section. American Fisheries Society, Corvallis

Bloch, B., Gravningen, K., Larsen, J. L. (1991). Encephalomyelitis among turbot associated with a picornavirus-like agent. Dis. aquat. Org. 10: 65-70

Blum, H., Beier, H., Gross, H. J. (1987). Improved silver staining of plant proteins, RNA and DNA in polyacrylamide gels. Electrophoresis 8: 93-99

Buchanan, J. S., Richards, R. H., Sommerville, C., Madeley, C. (1978). A herpes type virus from turbot (Scophthalmus maximus). Vet. Rec. 102: 527-528

Castric, J., Baudin-Laurencin, F., Coustans, M. F., Auffret, M. (1987). Isolation of infectious pancreatic necrosis virus Ab serotype from epizootics in farmed turbot, Scophthalmus maximus. Aquaculture 67: 117-126

Christie, K. E., Havarstein, L. S., Djupvik, H. O., Endresen, C. (1988). Characterization of a new serotype of infectious pancreatic necrosis virus isolated from Atlantic salmon. Arch. Virol. 103: 167-177

Dobos, P., Rowe, D. (1977). Peptide map comparison of infectious pancreatic necrosis virus specific polypeptides. J. Virol. 32: 805-820

Dorson, M. (1983). Infectious pancreatic necrosis of salmonids. An overview of current problems. In: Anderson, D. P., Dorson, M. M., Douborget, P. (eds.) Antigens of fish pathogens. Fundation Marciel Merieux, Lyon, p. 7-32

Dopazo, C. P. (1991). Caracterización de birnavirus y rotavirus de peces: propiedades biológicas, serológicas y moleculares. Doctoral dissertation, Universidad de Santiago de Compostela

Dopazo, C. P., Toranzo, A. E., Samal, S. K., Roberson, B. S., Baya, A., Hetrick, F. M. (1992). Antigenic relationship among rotaviruses isolated from fish. J. Fish Dis. 15: 27-36

Dorson, M., Torchy, C. (1981). The influence of fish age and water temperature on mortalities of rainbow trout, Salmo gairdneri Richardson, caused by a European strain of infectious pancreatic necrosis virus. J. Fish Dis. 4: 213-221

Fernández-Puentes, C., Novoa, B., Núnez, S., Figueras, A. J., Toranzo, A. E. (1991). The turbot diseases in a Galician farm (Spain): one year study. European Aquaculture Society, Spec. Publ 14: $97-98$

Responsible Subject Editor: F. M. Hetrick, College Park, Maryland, USA
Hedrick, R. P., Eaton, W. D., Fryer, J. L., Groberg, W. G., Boonyaratapalin, S. (1986). Characteristics of a birnavirus isolated from cultured sand goby Oxeleotris mamoratus. Dis. aquat. Org. 1: 219-225

Hill, B. J. (1982). Infectious pancreatic necrosis virus and its virulence. In: Roberts, R. J. (ed.) Microbial diseases of fish, Vol. 9. Academic Press, New York, p. 91-114

Kuchler, R. J. (1977). Biochemical methods in cell culture and virology. Dowden, Hutchinson and Ross, Inc., Stroudsburg, PA

Laemmli, U. K. (1970). Cleavage of structural proteins during the assembly of the head of bacteriophage T4. Nature $227: 680-685$

Ledo, A., Lupiani, B., Dopazo, C. P., Toranzo, A. E., Barja, J. L. (1990). Fish viral infections in the Northwest of Spain. Microbiologia 6: 21-29

Lupiani, B., Dopazo, C. P., Ledo, A., Fouz, B., Barja, J. L., Hetrick, F. M., Toranzo, A. E. (1989). A new syndrome of mixed bacterial and viral etiology in cultured turbot (Scophthalmus maximus L.). J. aquat. Anim. Health 1. $197-204$

McAllister, P. E., Newman, M. W., Sauber, J. H., Owens, W. J. (1984). Isolation of infectious pancreatic necrosis virus (serotype A.b) from diverse species of estuarine fish. Helgoländer Meeresunters. 37: 317-328

McAllister, P. E., Owens, W. J. (1986). Infectious pancreatic necrosis virus: protocol for a standard challenge to brook trout. Trans. Am. Fish. Soc. 115:466-470

MacDonald, R. D., Gower, D. A. (1981). Genomic and phenotypic divergence among three serotypes of aquatic Birnaviruses (Infectious Pancreatic Necrosis Virus). Virology 114: $187-195$

Mortensen, S. H., Hjeltnes, B., Rodseth, O., Krogsrud, J., Chistie. K. E. (1990). Infectious pancreatic necrosis virus, Serotype N1, isolated from Norwegian halibut (Hippoglossus hippoglossus), turbot (Scophthalmus maximus) and scallops (Pecten maximus). Bull. Eur. Ass. Fish Pathol. 10(2): $42-43$

Novoa, B., Figueras, A. J., Ledo, A., Barja, J. L., Toranzo, A. E. (1991). Incidence of birnavirus in cultured turbot (Scophthalmus maximus L.) in Northwest Spain. FHS/AFS Newsletter 19(2): $2-3$

Reed, L. J., Müench, H. (1938). A simple method of estimating fifty per cent end-points. Am. J. Hyg. 27: 493-497

Samal, S. K., Dopazo, C. P., Subramanian, K., Lupiani, B., Mohatny, S., Hetrick, F. (1991). Heterogeneity in the genome RNAs and polypeptides of five members of a novel group of rotavirus-like viruses isolated from marine animals. J. gen. Virol. 72: 181-184

Sano, T., Okamoto, N., Nishimura, T. (1981). A new viral epizootic of Anguilla japonica Temminck and Schlegel. J. Fish Dis. 4: 127-139

Scholtfeldt, H. J., Ahne, W., Vestergård-Jørgensen, P. E., Glende, W. (1991). Occurrence of viral haemorragic septicaemia in turbot (Scophthalmus maximus). A natural outbreak. Bull. Eur. Ass. Fish Pathol. 11(3): 105-107

Toranzo, A. E., Santos, Y., Bandín, I., Romalde, J. L., Ledo, A., Barja, J. L. (1990). Five year survey of bacterial fish infections in continental and marine aquaculture in the northwest of Spain. World Aquaculture 21: 91-94

Vestergård-Jørgensen, P. E. (1972). Egtved virus: antigenic variation in 76 virus isolates examined in neutralization tests and by means of the fluorescent antibody technique. Symp. zool. Soc. Lond. 30: 333-340

Manuscript first received: March 9, 1992

Revised version accepted: December 17, 1992 